\title{
Ako vníma materinský jazyk slovenská mládež v Mad'arsku a na Slovensku?
}

(Etnolingvistická reflexia)

\author{
MÁRIA HOMIŠINOVÁ \\ Spoločenskovedný ústav CSaPV Slovenskej akadémie vied, Karpatská 5, SK-040-01 Košice, \\ Filozofická fakulta Prešovskej univerzity, ul. 17. novembra 1, SK-080-01 Prešov \\ E-mail: homisin@saske.sk
}

(Received: 8 September 2015; accepted: 12 November 2015)

\begin{abstract}
The intention of this paper is to present the empirical research results of the Slovak youth lingual-communication behaviour in Slovakia and Hungary, whereas this research work was performed in both countries in the year 2010. Expressions of a spoken form of the Slovak language were investigated in surroundings which are typical for the application of the written language as a form of a social contact in school: with friends, peers, and in the family. The referential framework of this paper consists of three levels of analysis: 1 . the analysis of communication skills in Slovak and Hungarian; 2. the analysis of the evaluation of life values; 3 . the correlation of these parameters: language communication skills versus the perception of ethnic values (mother tongue).
\end{abstract}

Keywords: communication, knowledge of languages, the Slovak language, the Hungarian language, generation context, ethnoliguistic aspect

\section{1. Úvod}

V komplexne (interdisciplinárne) pojatom výskume zameranom na socioetnickú a jazykovú situáciu slovenskej mládeže žijúcej na Slovensku a v Mad’arsku, sme sa zamerali na skúmanie jazykovo-komunikačného správania v sociologickom, sociolingvistickom, etnokultúrnom a sociálnopsychologickom kontexte.

Sociálnopsychologický kontext výskumu zahrňoval aj problematiku životných hodnôt, ktoré možno považovat' za centrum integrujúce osobnost' človeka (Allport 1927). Dôležité je uvedomit' si, že internalizácia prevládajúcich hodnôt sociálneho prostredia jednotlivcom je proces sprevádzajúci jeho celoživotný psychosociálny vývin (VÝrost 2011). Vo vzt'ahu k téme, ktorej sa budeme venovat', je dôležité, že hodnoty sú významným stavebným kameňom (etnickej) identity človeka (HutNik 1992). Osobitne to platí v prípade, že jednotlivec je členom nejakej minority. Treba si uvedomit' (MosCovici 1979), že prakticky každý človek opakovane zažije v priebehu svojho života skúsenost' (situáciu) príslušnosti k nejakej podobe minority (rasovej, etnickej, náboženskej, rodovej, názorovej a pod.)

V predchádzajúcom čísle tohto časopisu sme prezentovali výskumné zistenia predmetného výskumu týkajúce sa stavu bilingvizmu (znalost' slovenského a mad’arského jazyka) a medzigeneračnej jazykovej komunikácie členov obidvoch jazy- 
kových skupín, t. j. slovenskej mládeže v Mad'arsku a na Slovensku (HomišınovÁ 2015). Uvedený príspevok je jeho bezprostredným pokračovaním. Tentoraz sme skúmali súvislosti stavu bilingvizmu slovenskej mládeže v kontexte posudzovania životných hodnôt (vrátane materinského jazyka). Inak povedané, kým v prvom článku nás zaujímal vplyv znalosti jazykov (slovenského aj mad'arského) na ich medzigeneračné používanie, teraz nás zaujíma vplyv znalosti jazykov na posudzovanie významu materinského jazyka ako etnickej hodnoty. Získame tak celistvejší obraz o tom, akú úlohu zohráva bilingvizmus slovenskej mládeže v obidvoch krajinách ako faktor každodennej komunikácie aj ako faktor integrácie osobnosti človeka.

V príspevku budeme analyzovat' výsledky dvoch ukazovatel'ov získané prostredníctvom časti aplikovaného dotazníka, nazvaného Škála jazykovej znalosti a Škála hodnôt. Konkrétne pôjde o ukazovatel' znalosti jazykových podôb slovenčiny a komunikačnej znalosti mad'arčiny a ukazovatel' postavenia materinského jazyka $\mathrm{v}$ hodnotovej hierarchii mladých l’udí. Naším primárnym zámerom je poukázat' na súvislosti vzájomného pôsobenia obidvoch vybraných ukazovatel'ov.

\section{Popis metodiky a vzt’ahový rámec analýzy}

Z celého radu výsledkov, na rôznych úrovniach analýz, prinášame zaujímavú informáciu o tom, ako komunikačná znalost' slovenského jazyka slovenskej mládeže súvisí s ich posúdením materinského (slovenského) jazyka ako hodnoty v hierarchii životných hodnôt. Výsledky sa týkajú jazykových skupín: 1. slovenskej mládeže žijúcej v národnostne zmiešanej (slovensko-mad’arskej) oblasti južného Slovenska (SS; N = 100 respondentov); 2 . slovensky hovoriacej mládeže $e^{1}$ žijúcej prevažne na juhu Mad'arska (SM; $\mathrm{N}=100$ respondentov).

V kontexte skúmania jazykových procesov slovenskej minority žijúcej prevažne v južných oblastiach Mad'arská (Dolná zem) zopakujeme, že jej jazykový vývin, vzhl'adom na ich špecifický vývoj a etnické charakteristiky (DIvIČANOvÁ 1999), sa uberal od monolingvizmu k nevyváženému bilingvizmu s výraznou dominanciou jazykovej komunikácie $\mathrm{v}$ mad'arskom jazyku a slabnúcim použivaním materinského jazyka v rodinnom prostredí (DiviČANová 2002, DiviČANOVÁ 2004; ŽILÁKOVÁ 2002, ŽILÁKOVÁ 2004; HoMišINOVÁ 2003, 2006, 2008a, 2011a, 2011 b; UHRINOVÁ 2004, 2008, 2011).

V kontexte skúmania preferencie hodnôt u slovensky hovoriacej mládeže je potrebne zdôraznit', že vzhl'adom na špecifiká slovenskej menšiny žijúcej v Mad'arsku a celkové hodnotenie uvedenej minority ako minority so slabým národnostným povedomím (DiviČANOVÁ 1999, 2002; HomišinOvá 2003, 2006; UhrinOVÁ 2004, 2011) sme predpokladali nevýrazné zastúpenie materinského jazyka v hierarchii ponúknutých životných hodnôt.

V súlade so stanovenými ciel'mi výskumného projektu, účelom použitej metodiky bolo skúmanie jazykovo-komunikačnej znalosti účastníkov výskumu (ovládanie majoritného a minoritného jazyka, t. j. slovenčiny a mad’arčiny u slovenskej

${ }^{1}$ Zachovajúc podmienky výberu výskumnej vzorky (pozri HoMıšINOvÁ 2011a). 
mládeže v obidvoch krajinách, avšak v opačnom garde) a posúdenie životných hodnôt (v rámci nich aj postavenie materinského jazyka).

Uvedené ukazovatele (empirické premenné) sme tak mohli skúmat' samostatne, ale aj vo vzájomných súvislostiach.

Referenčný rámec článku obsahuje tri roviny analýz, ktoré interpretujeme z pohl'adu obidvoch jazykových skupín: 1. analýza komunikačnej znalosti majoritného a minoritného jazyka ${ }^{2}$ (hodnotenie na osobnej úrovni, t. j. za seba); 2. analýza desiatich životných hodnôt; 3. vzájomné súvislosti ukazovatel'ov: komunikačná znalost' jazykov vs. vnímanie materinského jazyka ako hodnoty.

\subsection{Ukazovatel' jazykovej znalosti}

Podstatou ukazovatel'a jazykovej znalosti bolo vlastné vyjadrenie resp. priznanie účastníkov výskumu k ovládaniu vybraných podôb slovenského jazyka a mad'arského jazyka (komunikačný jazyk majority v Mad'arsku a minority na Slovensku). Hoci sme vo výskume sledovali fungovanie spisovnej slovenčiny predovšetkým ako jej hovorenej podoby, v uvedenom ukazovateli sme z dôvodu jasnejšieho vymedzenia jazykových podôb špecifikovali spisovný slovenský jazyk a hovorovú podobu slovenčiny, ktorých chápanie sme bližšie označili. V prípade mad'arského jazyka sme predpokladali, že obidve jazykové skupiny, ako kontaktné skupiny s mad’arským etnikom, disponujú istou mierou komunikačnej znalosti mad'arčiny. Ukazovatel' jazykového správania v uvedenom kontexte poukazoval (s istými obmedzeniami) aj na stav bilingvizmu vybraných jazykových skupín.

Otázka aplikovaná v metodike výskumu sledovala aj priznanie miery ovládania jazykov. Išlo o schopnost' rozprávat' v spisovnom slovenskom jazyku (jazyk akým sa hovorí v TV, rozhlase), hovorovej slovenčine (bežný jazyk komunikácie), slovenskom nárečí, mad'arskom jazyku. Respondenti na sedembodovej posudzovacej (ratingovej) škále hodnotili mieru svojej znalosti, resp. svoju komunikačnú schopnost' v slovenskom a mad'arskom jazyku.

Znenie otázky bolo nasledovné:

Čo si myslite, do akej miery Vy osobne ovládate uvedený jazyk?

\begin{tabular}{|c|c|c|c|c|c|c|}
\hline 1 & 2 & 3 & 4 & 5 & 6 & 7 \\
\hline $\begin{array}{c}\text { vôbec } \\
\text { nerozprávam }\end{array}$ & & & $\begin{array}{c}\text { priemerne } \\
\text { rozprávam }\end{array}$ & & & $\begin{array}{c}\text { vel'mi dobre } \\
\text { rozprávam }\end{array}$ \\
\hline
\end{tabular}

V uvedenom príspevku sa zameriame na všetky tri podoby slovenského jazyka a tiež mad'arského jazyka v zmysle ich posudzovania respondentmi ako komunikačného prostriedku.

${ }^{2} \mathrm{~V}$ prípade slovenskej mládeže v Mad’arsku išlo o slovenský jazyk, v prípade slovenskej mládeže na Slovensku išlo o mad’arský jazyk ako jazyk mad’arskej minority spolu žijúcej na národnostne zmiešanom území Slovenska. 


\subsection{Ukazovatel' hodnôt}

Účelom metodiky bolo aj posúdenie postavenia materinského jazyka a národnostnej príslušnosti v hodnotovej hierarchii respondentov. Preto bolo potrebné ponúknut' zoznam hodnôt, v ktorom boli zahrnuté aj spomínané položky.

Uskutočnil sa výber 10 hodnôt $(\mathrm{a}-\mathrm{j})$, ktoré tematicky tvorili 3 oblasti hodnôt:

1. personálne hodnoty: vzdelanie, zdravie, rodina, zamestnanie, majetok, vierovyznanie;

2. etnické hodnoty: materinský jazyk, národnostná príslušnost';

3. sociálne hodnoty: sloboda, demokracia. ${ }^{3}$

$\mathrm{Na}$ vyjadrenie miery uprednostňovania prezentovanej hodnoty respondentmi bola použitá 7-bodová posudzovacia (ratingová) škála.

Vyznačte prosím, akú dôležitost' (význam) pripisujete nasledujúcim hodnotám:

f) materinský jazyk

\begin{tabular}{|c|c|c|c|c|c|c|}
\hline 1 & 2 & 3 & 4 & 5 & 6 & 7 \\
\hline vôbec žiadny & & & priemerný & & & vel'mi vel'ký \\
\hline
\end{tabular}

V uvedenom príspevku sa zameriame na materinský jazyk v zmysle jeho posudzovania respondentmi ako etnickej hodnoty.

\section{Výsledky}

Výsledky realizovaných analýz budeme interpretovat' v zmysle skôr uvedeného referenčného rámca zachovajúc spomínané tri línie analýzy.

\subsection{Komunikačná znalost' jazykov}

V avizovanom článku „Ako hovorí slovenská mládež v Mad'arsku a na Slovensku?" sme sa venovali podrobnejším analýzam týkajúcim sa stavu bilingvizmu u výberových skupín výskumu a zist’ovali sme mieru komunikačnej znalosti (frekvenčná analýza, analýza rozptylu, poradová korelácia). Na tomto mieste, z dôvodu l'ahšej orientácie v texte a lepšej porovnatel'nosti súvzt’ažných analýz dvoch skúmaných ukazovatel'ov, predstavíme výsledky v kategorizovanej podobe. Spomínanú sedembodovú škálu skúmanej premennej sme zoskupili do 3 kategórií odpovedí, ktoré signalizovali:

1 - podpriemernú (slabú až žiadnu) komunikačnú znalost' príslušnej jazykovej podoby (zlúčenie negatívnych bodov 1, 2, 3);

2 - priemernú (uspokojivú) mieru komunikačnej znalosti (stredný bod 4);

3 - nadpriemernú (dobrú až vel'mi dobrú) mieru komunikačnej znalosti (zlúčenie pozitívnych bodov $5,6,7)$.

\footnotetext{
${ }^{3}$ Uvedený článok sa nezaoberá vnútornou štruktúrou škály hodnôt a zistením ich vnútornej konzistencie ani zoskupením hodnôt do jednotlivých oblastí a ich porovnaniu (pozri VÝROST 2011).
} 
Týmto spôsobom sme vytvorili tri podskupiny respondentov ${ }^{4} \mathrm{v}$ každej výberovej skupine, ktoré reprezentovali príslušnú mieru komunikačnej znalosti jazykových podôb slovenského jazyka a mad’arského jazyka.

$\mathrm{Z}$ takto realizovaných analýz vyplynuli výsledky, ktoré ilustratívne predstavujeme prostredníctvom grafu č. 1 .

Graf č. 1

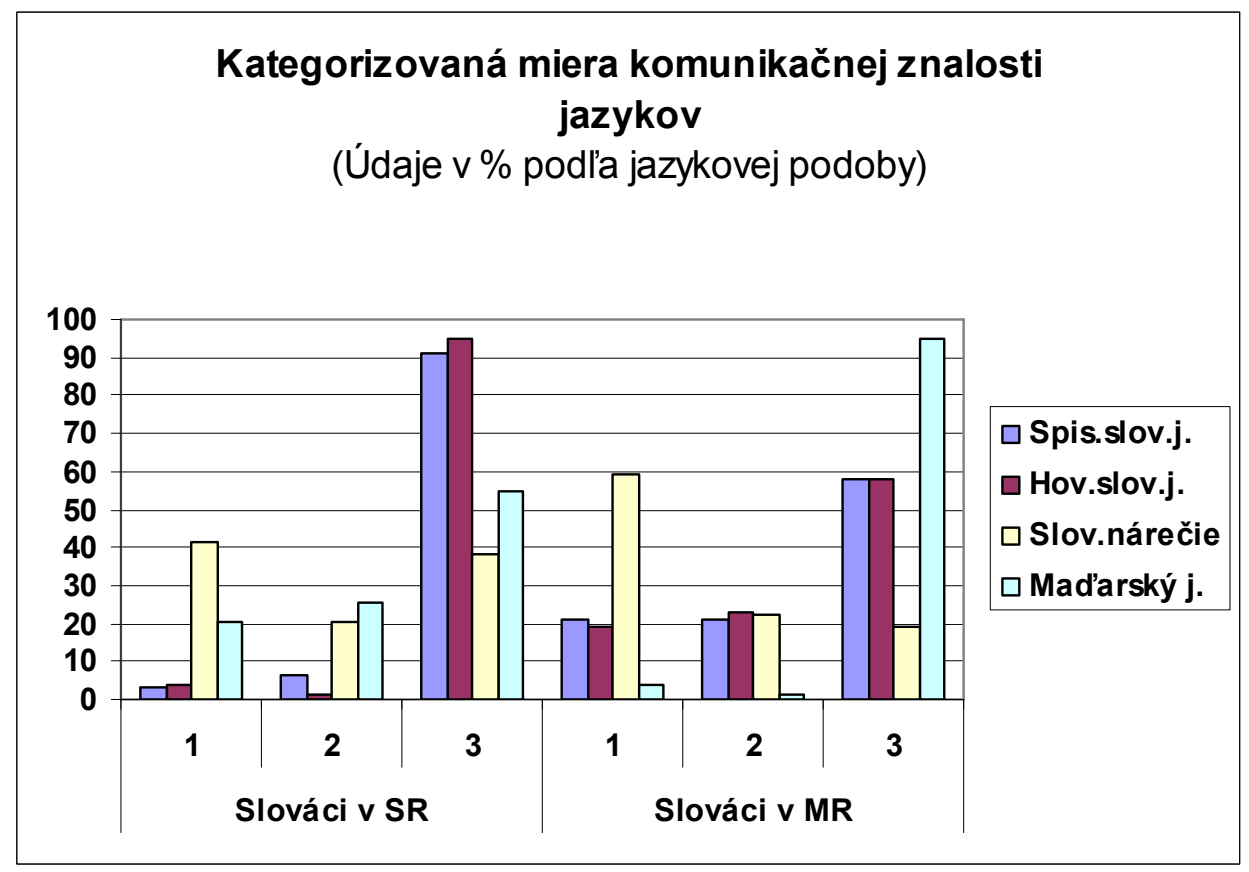

\section{Legenda:}

1 - podpriemerná (slabá až žiadna) komunikácia;

2 - priemerná (uspokojivá) miera komunikácie;

3 - nadpriemerná (dobrá až vel’mi dobrá) komunikácia.

Aj z tohto pohl'adu analýz je na prvý pohl'ad zrejmé, že miera komunikačnej znalosti jednotlivých jazykových podôb sa medzi slovenskou mládežou na Slovensku a v Mad’arsku navzájom diferencuje. Rozdiely medzi skupinami v hodnotení komunikačnej znalosti skúmaných jazykov sú štatisticky významné, pričom najväčšie rozdiely produkuje mad’arský jazyk $\left(\mathrm{p} \leq 0,000 ; \chi^{2}=44,1\right)$ a dve podoby slovenského jazyka: spisovná slovenčina $\left(\mathrm{p} \leq 0,000 ; \chi^{2}=28,74\right)$ a hovorová slovenčina $\left(\mathrm{p} \leq 0,000 ; \chi^{2}=38,47\right)$. Komunikácia $\mathrm{v}$ slovenskom nárečí vykazuje síce menšie diferencie medzi skupinami Slovákov, avšak rovnako štatisticky významné $\left(\mathrm{p} \leq 0,01 ; \chi^{2}=9,66\right)$.

\footnotetext{
${ }^{4}$ Takáto kategorizácia odpovedí (nepriamo aj respondentov) bola vytvorená účelovo, výlučne len pre potreby výskumných analýz. Uvedomujeme si, že meranie komunikačnej znalosti je zložitejší problém a nesporne presahuje tri nami vytvorené kategórie.
} 
Pri pohl'ade na výsledky vidíme zaujímavú skutočnost', ked' obidve skupiny sa celkovo zhodli vo vyjadrení „dobrej až vel'mi dobrej“ komunikačnej znalosti spisovnej aj hovorovej slovenčiny, hoci percentuálne v odlišnej miere. Kým u SS to bola takmer celá výskumná vzorka ( $\mathrm{SS}_{99}$ : $90,9 \%$ a $95 \%$ ), u SM sa za takúto mieru komunikácie $\mathrm{v}$ obidvoch spomínaných podobách slovenského jazyka zhodne vyjadrila viac ako polovica respondentov $\left(\mathrm{SM}_{100}: 58 \%\right)$. Čo sa týka komunikačnej znalosti mad’arského jazyka zaznamenávame percentuálne výsledky v opačnom garde $\left(\mathrm{SS}_{99}=54,5 \% ; \mathrm{SM}_{100}=95 \%\right)$.

Z tohto aspektu analýz sa teda u SM a SS potvrdil tzv. „krížový efekt“ používania slovenského a mad’arského jazyka, a to pri zachovaní miery komunikačnej znalosti (dobrá až vel'mi dobrá znalost') a zachovaní takmer identického počtu zastúpenia respondentov, ktorí znalost' jazykov posudzovali. Inak povedané, kým SM preferujú v komunikácii mad’arský jazyk pred slovenským jazykom, ${ }^{5}$ naopak, SS preferujú slovenský jazyk pred mad’arským jazykom.

Z pohl'adu nášho výskumného ciel’a je podstatné, že obidve skupiny zhodne, v nadpolovičnej väčšine, potvrdili aj znalost’ minoritného/majoritného jazyka ako sekundárneho jazyka (v prípade SM slovenský jazyk, v prípade SS mad'arský jazyk). V prípade SM ide zrejme o úsilie zachovat' slovenský materinský jazyk, v prípade SS ide pravdepodobne o dôsledok dlhodobého spolužitia s mad'arskou minoritou na Slovensku.

V d’alších analýzach nás bude zaujímat', či komunikačná znalost' hovorovej slovenčiny nejako súvisí s posúdením materinského jazyka ako etnickej hodnoty. Skôr však venujeme pozornost' výsledkom posúdenia životných hodnôt.

\subsection{Posúdenie životných hodnôt}

Jednoduchú orientáciu v získaných výsledkoch poskytuje preferencia jednotlivých hodnôt v obidvoch skupinách. Táto informácia tvorí obsah nasledovnej tabul'ky:

Tab. č. 1: Preferencia hodnôt slovenskej mládeže v Mad'arsku a na Slovensku

\begin{tabular}{|l|c|c|l|c|c|}
\hline $\begin{array}{l}\text { Hodnoty/slovenská } \\
\text { mládež v Mad'arsku }\end{array}$ & Priemer & Poradie & $\begin{array}{c}\text { Hodnoty/slovenská } \\
\text { mládež na Slovensku }\end{array}$ & Priemer & Poradie \\
\hline a) zamestnanie & 5,64 & $6 .-7$. & a) zamestnanie & 6,35 & 4. \\
\hline b) sloboda & 6,01 & 3. & b) sloboda & 6,36 & 3. \\
\hline c) vzdelanie & 5,88 & 5. & c) vzdelanie & 6,34 & 5. \\
\hline d) zdravie & 6,55 & 2. & d) zdravie & 6,89 & 1. \\
\hline e) demokracia & 5,64 & $6 .-7$. & e) demokracia & 5,78 & 6. \\
\hline f) materinský jazyk & 5,99 & 4. & f) materinský jazyk & 5,39 & 7. \\
\hline g) rodina & 6,66 & 1. & g) rodina & 6,79 & 2. \\
\hline h) národnost' & 5,09 & 8. & h) národnost' & 4,17 & 9. \\
\hline i) majetok & 4,85 & 9. & i) majetok & 5,03 & 8. \\
\hline j) náboženstvo & 3,69 & 10. & j) náboženstvo & 3,45 & 10. \\
\hline
\end{tabular}

${ }^{5}$ Opätovne sa u nich potvrdila dominancia mad’arského jazyka ako primárneho komunikačného jazyka a sekundárna pozícia slovenského jazyka. 
Z tabul'ky je zrejmé, že respondenti obidvoch skupín za najdôležitejšie hodnoty (z uvedených) považujú zhodne rodinu, zdravie a slobodu. Ich poradie je však na prvých dvoch miestach zamenené, u SM dominuje rodina a u SS zdravie.

Ak porovnáme poradie 10 singulárnych (jednotlivých) hodnôt, zistíme, že rozdiely produkuje najmä umiestnenie dvoch hodnôt (rozdiel poradí väčší ako dve poradové miesta):

- „Materinský jazyk“, ktorý sa v hodnotovej hierarchii slovenskej mládeže v Mad’arsku umiestnil na 4. mieste, kým v druhej skupine je na 7.pozícii;

- „Zamestnanie“, ktoré sa v hodnotovej hierarchii slovenskej mládeže v Mad'arsku umiestnilo na 6.-7. mieste. kým u slovenskej mládeže je na Slovensku na 4. mieste.

Čo sa týka „Národnosti“ u slovenskej mládeže v Mad’arsku sa ako etnická hodnota umiestnila na 8. mieste, kým u slovenskej mládeže na Slovensku až na 9. mieste. Z toho je zrejmé, že „Materinský jazyk“ aj „Národnost”“ ako etnické hodnoty sú v poskytnutej hierarchii hodnôt mladou generáciou v Mad’arsku viac preferované. Zrejme to vyplýva $\mathrm{z}$ ich minoritného postavenia a uvedomenia si ich dôležitosti a významu (zvlášt' to platí pre postavenie materinského jazyka).

Detailnejšiu informáciu posudzovania materinského jazyka ako hodnoty poskytuje frekvenčná analýza, ktorej výsledky prinášame prostredníctvom grafu č. 2.

Graf č. 2

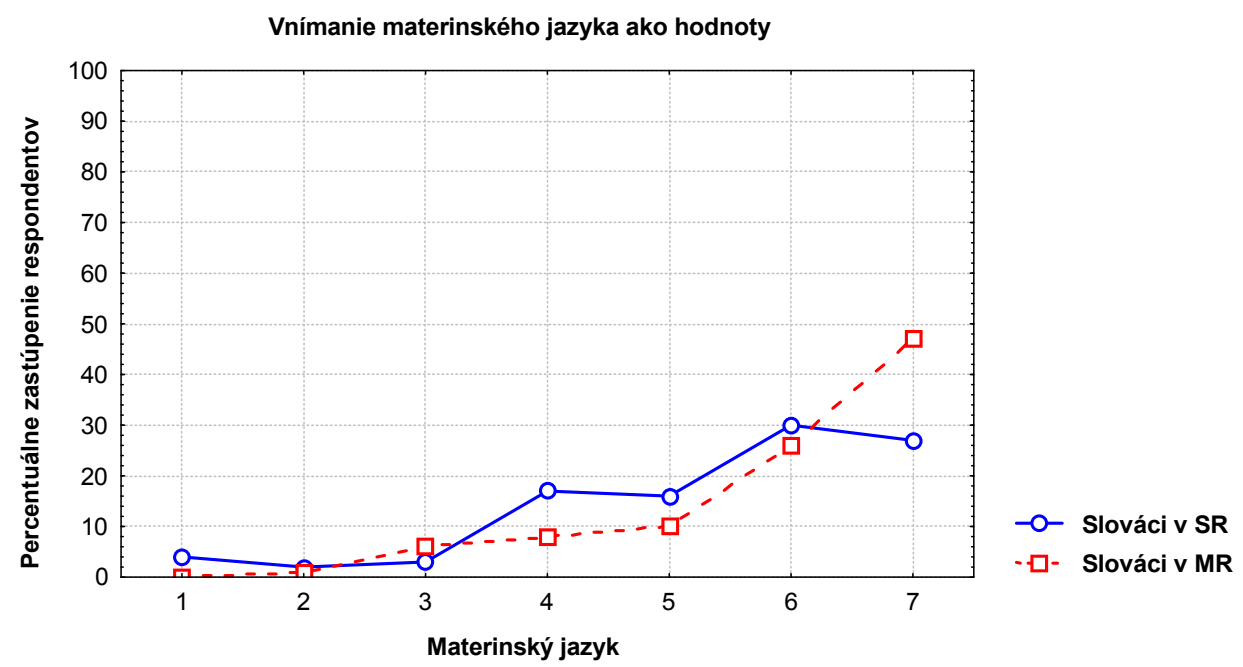

Graf naznačuje rozdiely vo vnímaní materinského jazyka ako hodnoty z pohl’adu jednotlivých skupín, ktoré sú celkovo štatisticky významné $\left(\mathrm{SS}_{99} ; \mathrm{SM}_{98}\right.$; $\left.\mathrm{p} \leq 0,016 ; \chi^{2}=15,64\right)^{6}$

Na sedembodovej posudzovacej škále hodnotili respondenti z Mad'arska materinský jazyk ako vel'mi dôležitú hodnotu (bod 7) vo výraznejšom počte (takmer

\footnotetext{
${ }^{6}$ Vzhl’adom na počet respondentov v obidvoch skupinách (takmer 100 respondentov) údaje v \% sú zhodné s počtom odpovedajúcich $(\mathrm{N})$.
} 
polovica z nich oproti necelej tretine respondentov zo Slovenska). Pomer respondentov pri sčítaní dvoch najvyššie postavených bodov na škále (6 a 7) naznačuje prevahu slovenskej mládeže z Mad'arska (tri štvrtiny respondentov) pri posudzovaní významu slovenského materinského jazyka ako hodnoty oproti slovenskej mládeže na Slovensku (viac ako polovica: 58\%).

Celkovo môžeme konštatovat', že aj detailnejšia analýza potvrdila vyššiu preferenciu materinského jazyka u SM.

\subsection{Vplyv komunikačnej znalosti hovorovej slovenčiny na posúdenie materinského jazyka ako hodnoty}

V d’alšej časti uvádzame najskôr výsledky analýzy rozptylu (ANOVA), kde ako nezávislé premenné (antecendent) vystupujú jazykové skupiny respondentov (slovenská mládež v Mad’arsku a na Slovensku) a 3 vytvorené kategórie miery znalosti hovorovej slovenčiny 1 - slabá až žiadna komunikácia, 2 - uspokojivá miera komunikácie, 3 - dobrá až vel'mi dobrá komunikácia, ako závislá premenná (konzekvent) materinský jazyk ako etnická hodnota. Výsledky z hl'adiska skúmania strednej hodnoty $(\bar{x})$ ilustruje graf č. 3 .

Graf č. 3

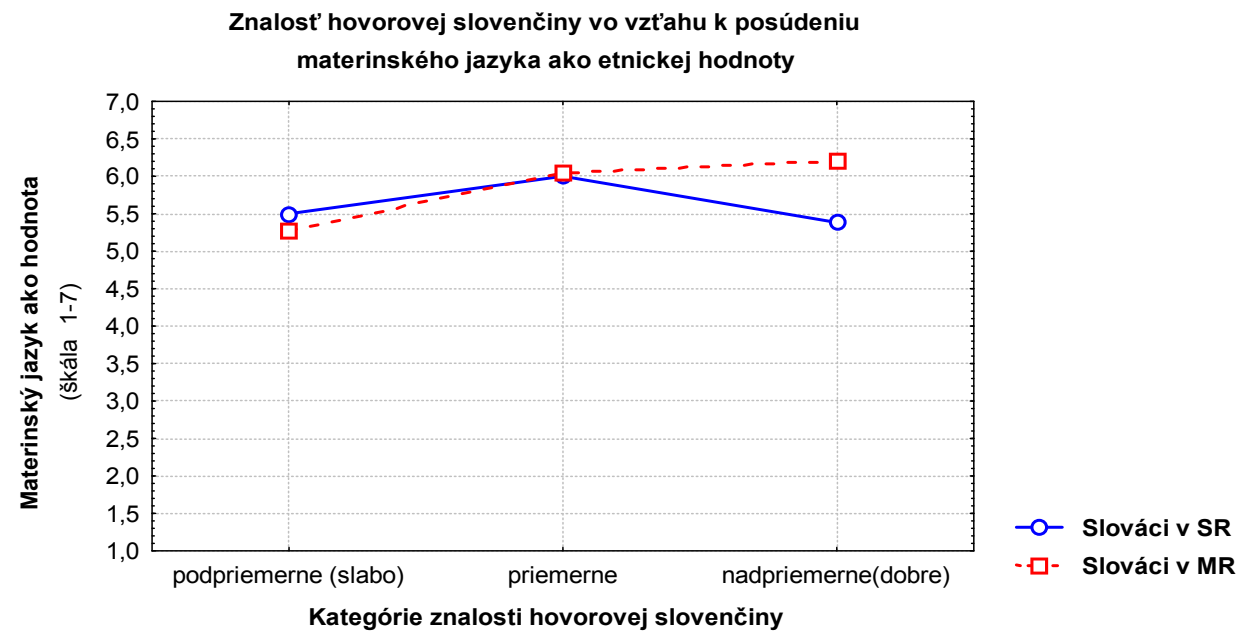

Z tohto pohl’adu analýzy sa nepotvrdili významné rozdiely v posudzovaní materinského jazyka ako hodnoty medzi skupinami vo vzt'ahu ku miere komunikačnej znalosti slovenčiny. Stredné hodnoty ukazovatel'a (materinský jazyk ako hodnota) v prípade obidvoch skupín respondentov, bez ohl'adu na mieru znalosti slovenčiny, sa nachádzajú v pozitívnom poli škály (medzi bodmi 5 a 6), čo znamená, že obidve skupiny respondentov, hoci s rozličnou mierou jej znalosti, materinskému jazyku pripisujú značný význam. Mierne rozdiely priemerných hodnôt vnímania materinského jazyka však produkuje skupina SM, ktorí sa vyjadrili, že nadpriemerne ovládajú slovenčinu (stredné hodnoty: $\mathrm{SS}=5,38 ; \mathrm{SM}=6,2$ ). Rozdiely sú však štatisticky nevýznamné. 
Ak sa však pozrieme na detailnejšiu analýzu predmetných ukazovatel'ov v rámci hodnotenia jednotlivých skupín (graf č. 4 a 5) na konkrétnej posudzovanej škále MJ ako hodnoty (1-7), zist'ujeme zretel'né rozdiely u obidvoch skupín (SM aj SS) hlavne u tých, ktorí sa zaradili do podskupiny dobre až vel'mi dobre komunikujúcich v hovorovej slovenčine. Práve tí prisudzujú slovenčine (jej hovorovej podobe) najvyšší význam. A hoci je to (v uvedenej kategórii komunikačnej znalosti slovenčiny) skupina SS, ktorí vo vyššom percentuálnom zastúpení preferovali materinský jazyk ako hodnotu (body $5+6+7$ u SS $=70 \%$ u SM $=52 \%$ ) u SM vidíme zretel'nejšiu tendenciu hodnotit' význam materinského jazyka na najvyššom stupni škály (bod 7: $25 \%$ oproti $29 \%$ ).

Graf č. 4

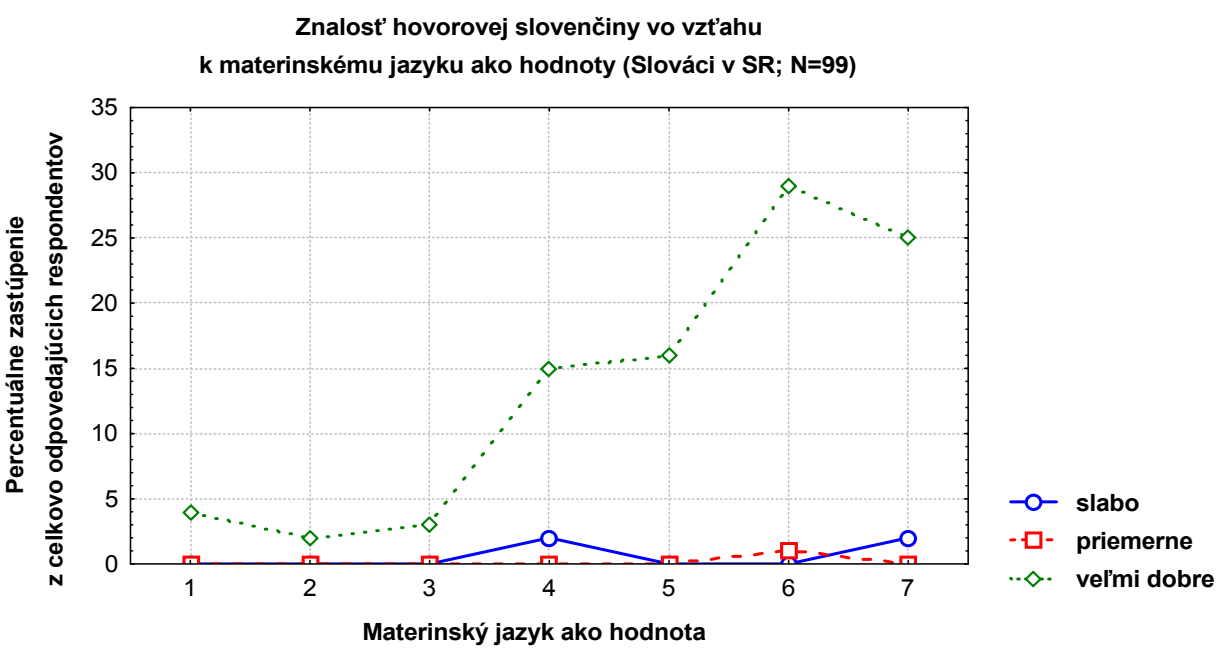

Graf č. 5

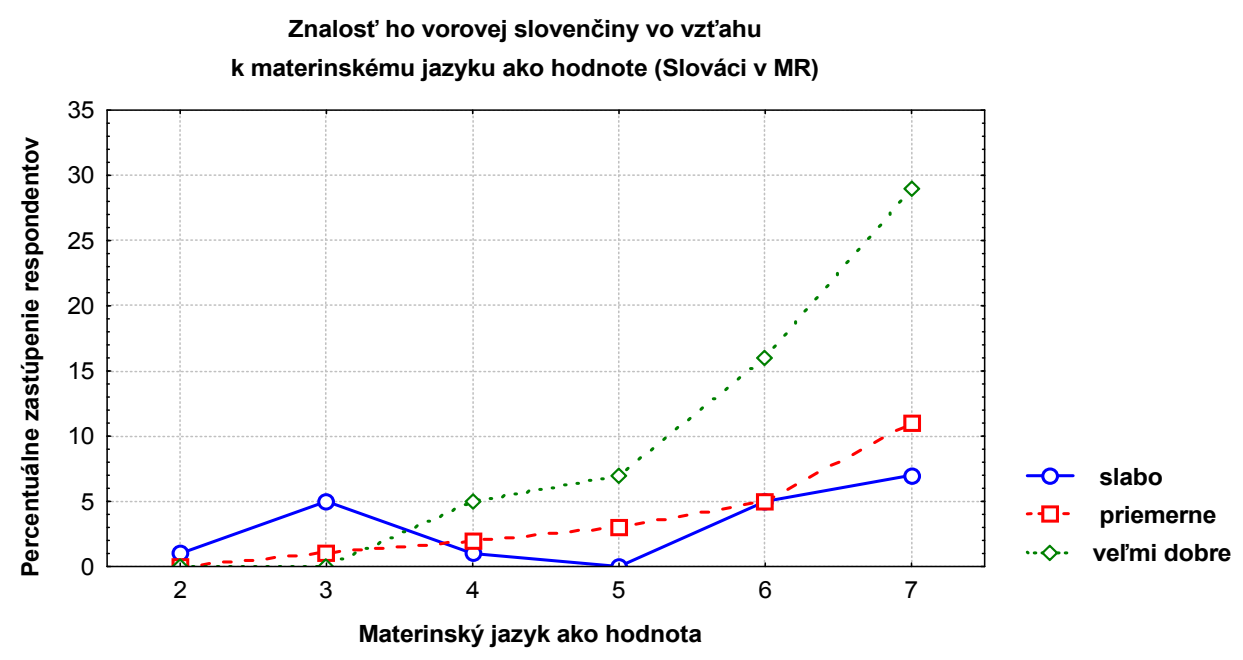


Z uvedených výsledkov môžeme celkovo konštatovat', že na úrovni detailnejších analýz sa u obidvoch skupín slovenskej mládeže (SM, SS) potvrdila súvislost' medzi komunikačnou znalost'ou hovorovej podoby slovenského jazyka a posudzovaním ich materinského jazyka ako životnej hodnoty. U obidvoch skupín sa prejavila zretel'ná tendencia: dobrá komunikačná znalost' slovenčiny predurčuje vnímat' svoj materinský jazyk (slovenský) ako významnú hodnotu.

\section{Sumarizácia a záver}

V príspevku sme sa sústredili na mieru komunikačnej znalosti bilingválne komunikujúcej slovenskej mládeže žijúcej v Mad’arsku a na Slovensku a tiež na posúdenie životných hodnôt vrátane materinského jazyka. Naším ciel'om bolo zistenie, či zohráva nejakú úlohu miera komunikačnej znalosti materinského jazyka (v našom prípade slovenčiny) na preferenciu materinského jazyka ako etnickej hodnoty. Opierali sme sa o výsledky empirického výskumu, realizovaného v roku 2010 v radoch slovenskej študujúcej mládeže na stredných a vysokých školách/ univerzitách $\mathrm{v}$ obidvoch krajinách.

Výsledky sumarizujeme z pohl'adu použitého referenčného rámca troch rovín analýz.

Prvá rovina analýz (komunikačná znalost' majoritného/minoritného jazyka):

- obidve skupiny zhodne v nadpolovičnej väčšine potvrdili znalost' minoritného aj majoritného jazyka ako sekundárneho jazyka (v prípade slovenskej mládeže v Mad’arsku: slovenský jazyk, v prípade slovenskej mládeže na Slovensku: mad'arský jazyk);

- rozdiely v miere komunikačnej znalosti jednotlivých jazykových podôb medzi slovenskou mládežou na Slovensku a v Mad'arsku produkuje mad’arský jazyk a dve podoby slovenského jazyka: spisovná slovenčina a hovorová slovenčina.

Druhá rovina analýz (posúdenie desiatich životných hodnôt):

- respondenti obidvoch skupín za najdôležitejšie hodnoty (z uvedených) považujú zhodne: rodinu, zdravie a slobodu;

- materinský jazyk sa v hodnotovej hierarchii slovenskej mládeže v Mad’arsku celkovo umiestnil na 4. mieste, kým u slovenskej mládeže na Slovensku na 7. pozícii;

- výsledky potvrdili vyššiu preferenciu materinského jazyka ako životnej hodnoty u skupiny slovenskej mládeže v Mad'arsku (trojštvrtinová prevaha oproti viac ako polovici slovenskej mládeže na Slovensku).

Tretia rovina analýz skúmania súvislostí ukazovatel'ov (komunikačná znalost' jazykov vs vnímanie materinského jazyka ako hodnoty):

- analýza rozptylu v prípade obidvoch skupín respondentov potvrdila umiestnenie strednej hodnoty v pozitívnom poli škály, čo znamená, že obidve skupiny respondentov, hoci s rozličnou mierou jej znalosti, materinskému jazyku pripisujú značný význam;

- detailnejšie analýzy u obidvoch skupín slovenskej mládeže potvrdili súvislost' medzi komunikačnou znalost'ou hovorovej podoby slovenského jazyka a po- 
sudzovaním ich materinského jazyka ako životnej hodnoty; u obidvoch skupín sa prejavila zretel'ná tendencia: dobrá komunikačná znalost' slovenčiny predurčuje vnímat' svoj materinský jazyk (slovenský) ako významnú hodnotu.

Po sumarizácii výsledkov (obidvoch článkov v predošlom a súčasnom čísle tohto časopisu) môžeme na záver konštatovat', že úroveň znalosti materinského jazyka (zvlášt' v minoritnom prostredí) je nielen determinujúcim faktorom komunikácie $\mathrm{v}$ ňom, ale zároveň aj faktorom upevnenia jeho výraznejšej pozície v hierarchii životných hodnôt. Potvrdilo sa, že zvlášt' slovenská mládež v Mad'arsku vníma materinský jazyk ako dôležitý hodnotový fenomén vo svojom živote.

\section{Literatúra}

Allport $1927=$ Allport G. W. Concepts of Trait and Personality. Psychological Bulletin 24 (1927): 284-293.

DiviČANOVÁ 1999 = DiviČANOvÁ Anna: Jazyk, kultúra, spoločenstvo. Etnokultúrne zmeny na jazykových ostrovoch v Mad'arsku. Békešská Čaba-Budapešt', 1999.

DiviČANOVÁ 2002 = DiviČANOVÁ Anna: Dimenzie národnostného bytia a kultúry. Békešská Čaba: Výskumný ústav Slovákov v Mad'arsku, 2002.

DiviČANOVÁ 2004 = DiviČANOvÁ Anna: Ambivalentné hodnoty slovenského jazyka v Mad'arsku v stredoeurópskom kontexte. In: UHRINOVÁ Alžbeta, ŽılíkOVÁ Mária (red.) Slovenčina v menšinovom prostredí. Békešská Čaba: Výskumný ústav Slovákov v Mad'arsku, 2004. 21-31.

HoMIŠINOVÁ 2003 = HoMIŠINOvÁ Mária: Slovenská inteligencia v Mad'arsku v zrkadle sociologického výskumu. Vybrané výsledky skúmania stavu etnickej identity. Békešská Čaba: Výskumný ústav Slovákov v Mad'arsku, 2003.

HomIŠINOvÁ 2006 = HomIŠINOvÁ Mária: Etnická rodina Slovákov, Chorvátov a Bulharov žijúcich v Mad'arsku v zrkadle sociologického výskumu. Teoretická a empirická komparativna analýza skúmania etnických procesov slovanských minorit. Békešská Čaba: Výskumný ústav Slovákov v Mad’arsku, 2006.

HoMIŠINOVÁ 2007 = HoMIŠINOVÁ Mária: Jazykovo-komunikačné správanie pracovníkov/ poslancov slovenských menšinových samospráv v Mad'arsku. Sociálne a politické analýzy 1 (2007): 102-135.

HoMIŠINOVÁ 2008a = HoMIŠINOVÁ Mária: Jazykovo-komunikačné správanie poslancov slovenských menšinových samospráv v Mad’arsku. In: UHRINOvÁ Alžbeta, TóTH Ján (red.): Slovenčina v menšinovom prostredi II. Békešská Čaba: Výskumný ústav Slovákov v Mad'arsku 2008. 461-469.

HomIŠINOVÁ 2008b = HoMIŠINOVÁ Mária: Identitás, nyelvhasználat, asszimiláció. Etnikai folyamatok a magyarországi kisebbségi családokban. Budapest: MTA Kisebbségkutató Intézet-Gondolat, 2008.

HomIŠINOVÁ 2011a = HoMišINOvÁ Mária: Koncept výskumného projektu jazykového správania slovenskej mládeže v Mad’arsku a na Slovensku. Človek a spoločnost' 2011/3. http://www.saske.sk/cas/zoznam-rocnikov/2011/3/5943.

HoMIŠINOVÁ 2011b = HoMIŠINOVÁ Mária: Jazyková znalost' a medzigeneračná jazyková komunikácia slovenskej mládeže na Slovensku a v Mad'arsku - empirický kontext. Človek a spoločnost' 2011/3. http://www.saske.sk/cas/zoznam-rocnikov/2011/3/5951.

HomišıNOVÁ 2015 = HomıšınOvÁ Mária: Ako hovorí slovenská mládež v Mad’arsku a na Slovensku v súčasnosti? Studia Slavica Hung. 60 (2015): 141-150. 
Hutnik 1992 = Hutnik N. Ethnic Minority Identity. A Social Psychological Perspective. Oxford: Clarendon Press, 1992.

Moscovici 1979 = Moscovici S. Psychologie des minorités actives. Paris: PUF, 1979.

PoliaCh 2007 = Poliach Vladimír: Sto rokov v psychológii hodnôt - autori, témy, publikácie. In: SALBot Vladimír (red.): Psychologické pohl’ady na osobné hodnoty. Banská Bystrica: UMB, 2007. 2-65.

UHRINOvÁ 2004 = UHRINOVÁ Alžbeta: Používanie materinského jazyka v kruhu slovenskej inteligencie v Békešskej Čabe. Békešská Čaba: Výskumný ústav Slovákov v Mad’arsku, 2004.

UHRINOVÁ 2008 = UHRINOVÁ Alžbeta: Slovenský jazyk v Mad'arsku očami používatel'ov. In: UhrinovÁ Alžbeta, ŽıláKovÁ Mária (red.): Slovenský jazyk v Mad'arsku I-II. Békešská Čaba: Výskumný ústav Slovákov v Mad’arsku, 2008. 92-224.

UhrinOvÁ 2011 = UhrinOvÁ Alžbeta: Súčasná slovenská jazyková situácia v Mad'arsku. Nadlak: Vydavatel'stvo Ivan Krasko, v spolupráci s Výskumným ústavom Slovákov v Mad'arsku, 2011.

VÝROST 2011 = VÝROST Jozef: Materinský jazyk v hierarchii hodnôt mladých l'udí slovenskej národnosti v Mad'arsku. Človek a spoločnost' 2011/3. http://www.saske.sk/cas/zoznam-rocnikov/2011/3/5944.

ŽILÁKOVÁ 2002 = ŽILÁKOvÁ Mária: Dvojjazyčnost' Slovákov v Mad'arsku. In: Bilingvizmus - minulost', pritomnost', budúcnost'. Zborník príspevkov z medzinárodného kolokvia o bilingvizme 22.2.2002 FF UK v Bratislave. Bratislava: AEP, 2002. 69-76.

ŽILÁKOVÁ 2004 = ŽILÁKOvÁ Mária: Dynamika jazyka Slovákov v Mad'arsku. Budapešt': ELTE BTK, 2004. 